\title{
Disappearing Acts, or the Absent Character in the Plays of Elena Garro
}

\section{Sandra Messinger Cypess}

Both in her professional and personal life, Elena Garro waged a sometimes-losing battle to keep herself from being ignored or silenced by the powerful of Mexico, as Elena Poniatowska has suggested (28). Such critics as Rebecca Biron, Gabriela Mora, Rhina Toruño, and Patricia Rosas Lopátegui treat her problems with the press and the public, and with her ex-husband, Octavio Paz, differently with regards to her difficulty in publishing her work from 1968 to 1980 . Whether she was "silenced" or disappeared from the cultural scene because of her eccentricities, as Biron suggests ("The Eccentric Elena Garro"), or because of a conspiracy against her, as Rosas Lopátegui maintains (El asesinato de Elena Garro), what is evident from her own texts is that many of her characters reflect her concerns about being silenced in an alien world. As Marta Robles writes, "hay vidas y obras que se funden en idéntico destino. Elena Garro bien podría ser uno de sus personajes mayores" (133). Supporting this idea, Biron reminds us that Garro often adopted her literary characters from her life (Elena Garro and Mexico's Modern Dreams 8 ), and many readers assume that there is no distinction between her characters and her life. ${ }^{1}$ I suggest, however, that although Garro resisted disappearing from public view, as a writer she imagined that there could be a positive side to absenting oneself from an unfavorable scene. One way that her characters deal with their disquiet or inconformity is to disappear, to absent themselves from the world they reject. Nevertheless, she also presents characters who are forced to absent themselves from their environment against their will, as Garro was forced to do after $1968 .^{2}$ While the most famous and well-studied examples of disappearing characters are from her narrative, in this study I focus on characters from her plays who literally disappear from sight. I suggest that the author uses these disappearances as a way of signaling that 
these characters can no longer function in the everyday world of Mexican social reality.

Julia Andrade and Felipe Hurtado of Los recuerdos del porvenir, Laura and Nacha of "La culpa es de los tlaxcaltecas," and Mariana and her daughter of Testimonios sobre Mariana have perhaps received the most critical attention as characters who disappear from Garro's fictive world. ${ }^{3}$ It should be noted, however, that of the first six dramatic pieces published in Un hogar sólido (1958), almost all have a person who disappears, including "Los pilares de doña Blanca," "El rey mago," "Andarse por las ramas," "Ventura Allende," and "El Encanto, Tendajón mixto." Again in the enlarged anthology of 1983, we see variations in both the characters who are taken away from their world and their disappearance, as in "Los perros," "Benito Fernández," and "La dama boba." In only a few plays the character who disappears is accompanied by a companion, such as Anselmo and the mysterious woman of "El Encanto, Tendajón mixto," or Benito and Victoria in "Benito Fernández." Many others disappear alone or unwillingly and point to another paradigm, as I shall demonstrate.

Readers familiar with Garro's fictive world are most likely to think of Julia Andrade and Felipe Hurtado as paradigmatic figures who disappear from their quotidian existence because they cannot express their true selves in their local setting. As we recall, it is Julia who is inaccurately blamed for all the misfortune in the village of Ixtepec: "Es Julia ... [quien] tiene la culpa de todo lo que nos pasa" (Los recuerdos 81 ). She is unable to tell her story to the villagers, to break out of the Malinche paradigm into which they have placed her, as I have suggested (La Malinche in Mexican Literature 154-57). Alone in a patriarchal society and unable to implement her independence, Julia is rescued by Felipe Hurtado. Felipe, a mysterious figure who arrives in Ixtepec, is the instrument through which Julia absents herself from the fears and dangers she faces in a place that misreads her every action. The scene in which they flee from Ixtepec and a dangerous destiny is well known as an example of magical realism. Time stops so that the two lovers can escape from the anger and maleficence of General Rosas. As the villagers are told by a muleteer who witnessed a horseman fleeing with a woman dressed in pink, "en el campo ya estaba amaneciendo y al llegar a las trancas de Cocula se topó con la noche cerrada" (145). They have left Rosas and the village, but where do they go? We are never told their final destination, only that it was not possible for them to express their love in the cruel world dominated by Rosas. Like Julia and Felipe, the couples who willingly vanish together 
in Garro's plays reach another existence in which they have more liberty and the power to express themselves.

One way of explaining their absence can be found in Walter Benjamin's theories on the art of communication. As Benjamin writes, "Less and less frequently do we encounter people with the ability to tell a tale properly.... It is as if something that seemed inalienable to us, the securest among our possessions, were taken from us: the ability to exchange experiences" (my emphasis, 362). Benjamin elaborates on this lessening of the communicative ability:

The art of storytelling is reaching its end because the epic side of truth, wisdom, is dying out. This, however, is a process that has been going on for a long time. And nothing would be more fatuous than to want to see in it merely a 'symptom of decay' let alone a 'modern symptom.' It is, rather, only a concomitant symptom of the secular productive forces of history, a concomitant that has quite gradually removed narrative from the realm of living speech and at the same time is making it possible to see a new beauty in what is vanishing." (my emphasis, 364)

Benjamin's ideas on the incommunicability of experiences in the contemporary world ${ }^{5}$ suggest that there are times and events for which those involved either cannot find the words to express their reactions or cannot find the appropriate listeners who can appreciate their experiences. While Benjamin clarifies how the historical moment has brought us to a period of incommunicability, he also suggests that this lack of ability to communicate experiences can produce "a new beauty in what is vanishing" (364). The characters who disappear as a couple illuminate Garro's view that they are escaping from the society in which they live, which for Garro reflects her own world, and must search for a reality other than the one they have been forced to live in. They leave because they are not understood — or, according to Benjamin, because they no longer can express their experiences to those around them. The irony here is that in the act of vanishing, the witnesses, both those in the fictive world and those of us in the audience, are forced to acknowledge this absence and perhaps contemplate what we have lost. ${ }^{6}$

Similar to Julia and Felipe is the couple that forms in "El Encanto, Tendajón mixto." Although the novel is replete with historical elements and involves many characters, I suggest that the main anecdote in the play serves as a kind of restatement of the need for escape that is explored in Los recuerdos del porvenir. In "El Encanto, Tendajón mixto," the events center 
on the differing reactions that three men demonstrate when faced with an out-of-the-ordinary experience. Anselmo Duque is the youngest of three humble muleteers who come upon a mysterious woman as they traverse el camino real. The name of the road is important, because as we readers/ spectators traverse that space with them, we are left to wonder whether it is the "royal" road, that is, the old Kings Highway or road system constructed in colonial times, or the "real" road, a reference to its existential nature. Not only is the road identified, but so is the date of their encounter - the third of May, a date that will repeat in the play. While each man has a specific name, the woman they meet is nameless in the cast list and identified only as "la mujer del hermoso pelo negro" (103). She makes her presence known to them at first as a voice that invites the three friends "[a] vivir embriagados" (107). As detailed in the stage directions, the voice emanates from behind a curtain, which suddenly opens to reveal a store on the road, and against the advice of his two older friends, Anselmo readily enters. He explains, "mis ojos todavía no han visto nada" (107), as if he were being drawn to the store and the woman because he is young, inexperienced, and in search of adventure. His earlier comments to his two older companions, while they were on the camino real, also reveal why he was so ready to accept the woman's invitation; Anselmo feels alienated from his environment and rejects the ability of the older men to help him. When Juventino tries to offer some consolation to Anselmo, the young man replies in a way that shows his distrust of his elders and their plodding ways: " $i \ldots$ a veces las palabras son estorbosas por faltar a la verdad!" (106). On the other hand, when Anselmo hears the mysterious woman's words, he tells her, “¡Dices verdad!” (109-10). While the other men fear the woman, Anselmo tells her, "Yo te veo como eres: resplandeciente como el oro, blandita como la plata, hija de las lagunas, rodeada de pájaros, patrona de los hombres... copa de vino buscada desde el primer día que fui Anselmo Duque, y hallada hasta este tres de mayo..." (113). Anselmo's vision is so positive that he alone accepts the wine she offers them. He believes that she can save him from his wearisome life filled with difficulties. He alone hears her words and considers them to be positive, while his companions fear her as "lisonjera" and "una aparición":

ANSELMO: (Adelantándose hacia la mujer) ¡Dices verdad! Yo sé que te bañas en ríos que jamás he visto, que te alimentas de algo que no es cualquier cosa, y que tus pies te trajeron aquí, para hacernos llevadera esta fatiga... Y también sé que mis ojos te han buscado desde que fueron mis ojos... 
MUJER: El hombre encuentra lo que busca. Y si a tus ojos vine, fue para darte algún encantamiento. (Levanta la mano, ofreciéndosela a Anselmo). (109-10)

As soon as Anselmo accepts the cup of wine offered to him by the mysterious woman, they both immediately disappear. Thus, unlike Julia and Felipe, it is the man who follows and the woman who serves as the guide out of the unfulfilling, dangerous world. We recall that Felipe had arrived mysteriously in Ixtepec and thus, it would seem, saved the life of Julia from the wrath and cruelty of Rosas, while here the mysterious woman serves as the guide to the true path for Anselmo.

Despite the rich significations in this play, there are few essays that focus on it, but one by Richard Callan offers a psychoanalytical reading in which the mysterious woman is identified as Mayauel, the Aztec goddess of pulque. Callan describes the union between Anselmo and Mayauel as a metaphor for the process of psychic maturity (49), using theories proposed by Carl Jung to support his reading. For example, the woman is "psychic energy, the psychological food for life" (56). For my study, what is important is the idea that the encounter is positive for Anselmo. Anselmo admits that the arrival of this woman is just what he was searching for, and that the woman also sees herself as representing something positive for men: "¿Acaso no buscaban la amable compañía de la mujer? Eso soy. Yo no acompaño de otra manera, porque así acompaña la mujer al hombre" (111).

Anselmo disappears with the mysterious woman, and with them, the store and the light that emanated from it also disappear, leaving his two companions in the dark, both literally and metaphorically. From their perspective, his disappearance is a tragedy, and they vow to search for him. They cannot understand his desire for escape from the camino real, a life of trials and tribulations, a life of poverty and deprivations. They return to the spot of his disappearance the following third of May, and as miraculously as he had disappeared, Anselmo returns with the mysterious woman. The stage directions indicate that he appears as if he had just finished his drink, as if time had not progressed from the last year, in that way almost recreating the tiempo detenido of the fleeing scene in Los recuerdos del porvenir. In this case, however, Anslemo's beard has grown, a sign of the passage of time. So it is not that time stood still, but as the woman says, "Él vive en otro tiempo..." (117). Anselmo has been guided by the woman to exist in another dimension, which appears to be more positive and enriching. Unlike the unknown outcome for Julia and Felipe, Anselmo has found a positive haven. Nevertheless, the muleteers 
believe they need to rescue him from this new-found world, unable to accept any other way but theirs, which is the camino real, or the material world of everyday reality.

The final scene of the play involves a battle of words between Anselmo and the woman on the one hand and the two muleteers on the other, with the men attempting to convince Anselmo to see their perspective and leave the woman. Anselmo's answer reiterates the problems that Benjamin described as the inability to share experiences, to see beyond the quotidian, a loss of wisdom: "Ella me dio los ojos para que mirara lo que ahora miro... y los sentidos para que entrara en los placeres que ahora encuentro..." (119). When the men ask him to explain, to relate to them his experiences with the woman, he attempts to do so, but they do not understand him, as Benjamin would have predicted. Anselmo's final warning to the men, the representatives of the old world he wants to leave, is definitive: "díganle que aquí me quedo...y que de aquí ni ella ni nadie me ha de sacar" (119). With those admonitions, Anselmo and the woman disappear again, leaving the old world of the camino real in shadows. While his disappearance with the woman of his dreams, as one might call her, ${ }^{7}$ might be considered a victory for Anselmo, it is considered a defeat for those who resist a new social order and want to maintain the status quo of relationships between women and men, between the poor and the rich. What Garro has highlighted in Los recuerdos del porvenir and even more forcefully in "El Encanto, Tendajón mixto" is the possibility to leave the everyday world of hardships and obstacles as long as one is escorted by a companion. The equality of the man and the woman here is more developed than in Los recuerdos del porvenir. Perhaps that is why Anselmo returns and attempts to tell of his discoveries. He is unsuccessful, however, because his audience does not want to hear about his experiences; they are not ready for such equality.

While the couple in "El Encanto, Tendajón mixto" offers perhaps the most successful union for Garro, her work rarely shows such positive encounters. Rather, her work focuses on the inability of women in particular to share their experiences and to be taken seriously in a patriarchal world, as we see in "Andarse por las ramas." This play provides another illustration of Benjamin's theories of incommunicability in the way Garro uses dramatic images on stage that concretize abstract ideas about feminism and incommunicability. The title is an excellent example of Garro's use of irony and her ability to play with signs. On the one hand, the phrase is generally taken as an idiom that translates as "to beat about the bush," that is, to not express 
oneself directly, whether out of desire to hide the truth or from fear of another's reactions. The literal meaning of the words in Spanish is to "walk along the branches" of a tree. In the play, the main character, Titina, will literally walk along the branches of a tree at the same time that her husband, Don Fernando de las Siete y Cinco, uses metaphoric language. Throughout the text, however, there is a continual play between the metaphoric and literal, as I have detailed in my analysis of the work in "Visual and Verbal Distances in the Mexican Theater: The Plays of Elena Garro." One must enjoy the irony in the fact that the husband, with his all-too-specific name, is also involved in word play without realizing it. In this play, Garro shows her sense of humor at the same time she treats a serious subject. She also shows another facet to the figure of the disappearing couple; Titina starts out with a partner, disappears from his view and his home, and almost finds another partner, only to end up unaccompanied in her new-found tree house, alone and invisible to the social milieu she rejects.

The play begins with a very quotidian scene: A husband, wife, and child are eating dinner. Titina, the wife, and Polito, the son, each sit at either side of the head of the house, Don Fernando. In his first words, he complains about his food being served late and also refers to a strange detail: "mis mancuernillas checoslovacas no aparecen" (69). Rather than respond directly, Titina mentions that in their world, "hay alguien que hace aparecer y desaparecer las cosas" (69). Disappearances and appearances, then, are not ruled by logic but by some mysterious force. As they continue a dialogue full of misunderstandings and obvious ideological differences, Don Fernando suddenly says to his wife, “ ¡Justina, Justina! ¡Te estoy hablando! ¡Responde!” (71). Without saying another word, Titina, as she is named in the list of characters, enacts a surprising series of gestures and movements that are detailed in the stage directions:

(Titina se levanta en silencio. Se dirige a los telones del fondo, saca de su pecho un gis rojo y sobre el muro dibuja una casita con su chimenea y su humito. Luego dibuja la puerta, la abre y desaparece. Encima del muro surgen las ramas de un árbol y Titina, sentada en una de ellas. Mientras tanto don Fernando habla, dirigiéndose a la silla vacía). (71)

Don Fernando continues to speak to Titina as if she were still in the chair at his side, as a good wife should be, but from the perspective of the audience, Titina is atop a tree outside the home! In his dialogue, Don Fernando admits that she is always trying to escape, and what is worse, she is teaching 
their son to "ir[se] por las ramas" (71). For Don Fernando, Titina is trying to avoid "la verdad," and when he says that she goes "por las ramas," he means metaphorically that she avoids the truth. In the semiotics of the play, Titina is literally "por las ramas" and it is Don Fernando who appears to be unaware of that reality. Ironically, he also declares that "Las mujeres viven en otra dimensión. La dimensión lunar" (71). We might see the argument as the conflict between differing ideologies - the rational vs. the magical, or in Benjamin's terms, those whose experiences are special vs. those who will not listen or see the uncommon. Thus, while Don Fernando may use an expression metaphorically - saying that women do not exist in the rational world - the audience may well interpret his actions as being irrational, while Titina appears to be doing literally what her words indicate. The two cannot understand each other. When Titina tries to explain to Don Fernando, he does not comprehend her words. Titina attempts to follow him when she gets down from the tree, erases the door she had drawn, and sits again at the table. Nevertheless, Don Fernando does not understand her actions and asks Titina to leave and not return until she becomes "rational," or as he says it, "Quiero verte con los pies en el suelo, no volando como una hoja" (73).

For Titina, being expelled from the patriarchal home is not a penance, but an opportunity. Her husband never really saw her true self, and so she seeks the outside world, looking for adventure. She meets another man, Lagartito, who also treats her in a traditional, machista fashion when he sees her in the street: "Tú, vagando por las esquinas" (74). She has become a woman of the streets, literally a streetwalker, but it is also implied that she is close to being a "loose" woman, or sexually free. ${ }^{8}$ Lagartito may first appear to be interested in her wellbeing, but he is just as incapable as Don Fernando of understanding her, as is demonstrated when, once again, Titina draws a tree and climbs atop the branches. Meanwhile, Lagartito addresses the empty space from which she has disappeared. In this play, the woman, Titina, disappears from the sight of the men without their realizing it. While they still address her, the fact that she is located above them and not in their sight is a clear comment on the lack of understanding between her and her supposed interlocutors. The idiomatic expression "to see eye-to-eye" would serve Garro as well in this play as in "El Encanto, Tendajón mixto," for in each one, the ability to see the other eye-to-eye indicates an understanding, a capacity to comprehend the reality of another person. Titina offers Lagartito an opportunity to see her as she is, from her perch above him. He appears to be following Anselmo when he says to her, "Déjame subir a sus ramas" 
(77), acknowledging that she is in the tree, but she does not allow him to rise up to her. On the contrary, she does not trust him, so she allows him only to hold her hand. He is below and she above, but to show her confidence that she is able to accept him in that way, Titina expresses her willingness to be faithful to Lagartito: "Así podríamos estar por los siglos de los siglos" (78). Nevertheless, her original intuition that he is not the one to join her in her tree is proven to be accurate. Another woman passes by, and Lagartito follows her with his eyes. Titina notices this and explains to him his true self: "Tus pies, Lagartito, están hechos para recorrer aceras, oficinas y señoras. Tus pies y tus ojos" (78). She understands his complexities and contradictions, while he does not understand himself. She lets go of him, since they do not see eye to eye, literally or metaphorically.

At the conclusion, Titina remains in the branches of the tree, unaccompanied and unseen. That is, Don Fernando passes by without seeing her, as does Lagartito, arm-in-arm with the woman he followed after leaving Titina. Lagartito's words end the play: "No te andes por las ramas. Uy, uy, uy" (78). One may conclude that Lagartito and Don Fernando are two different types of men in Mexican society, one too enmeshed in details and the other false inside and superficial. Neither one understands Titina, and for that reason she is invisible to them. Her attachment to the tree is significant, since it places her above the men, out of reach but still in the world of nature. She cannot, and would not want to, return to Don Fernando, who is waiting for her to have her "feet on the floor," neither can she, nor does she want to, be part of a couple with Lagartito, who is made for "aceras y oficinas." While the play does not provide the opportunity for Titina to form part of a couple and share her love, at least she is able to make her own decisions, to express an agency that is not always available to women in a typical patriarchal society.

A play that presents women in a more typical manner, that is as individuals with little control to resist the powerful men in their society, is "Los perros." Garro presents the terrors and violence of sexual abuse as she depicts the lives of two women, a mother and daughter, whose existence is circumscribed by the specter of rape. The feminist aspects of this play and its social significance have been well studied by a number of critics, including Gabriela Mora, Lucía Melgar, and Jessica Burke. As Mora notes, "El 'mundo mágico' de Garro está bien asentado en la realidad, que ella mira con ojos diferentes, pero muy abiertos a los males sociales" (13). Certainly "Los perros" is more explicit in its depiction of social ills than either "El Encanto, Tendajón mixto" or "Andarse por las ramas," yet all three plays attempt to impart Garro's vision 
of how incommunicability affects human interactions and often brings about social harm. My reading of "Los perros" recognizes what Melgar, Mora, and Burke, for example, have pointed out as the noxious social reality represented in the play and explores how the inability to share experiences leads to the tragic repetition of rape and violence against women. In "Los perros," the theme of rape is shown to be not only a concomitant factor of a machista society in which men take what they want, but one in which women are not only victims but enablers.

Benjamin decries the loss of storytelling, noting that the "communicability of experience is decreasing," and as a consequence, "we have no counsel either for ourselves or for others. After all, counsel is less an answer to a question than a proposal concerning the continuation of a story which is just unfolding" (364). I see the tragedy of the harsh subjugation of the three women in this play - Manuela's mother, Manuela, and her daughter, Úrsula — as part of their inability to tell their story and be acknowledged for what they have suffered. Manuela does not tell her complete story to her daughter until the end of the play, when it is too late for her wisdom and shared experiences to be of any value to her daughter. It should be noted that generally in Garro's fictive world, interactions between mother and daughter are positive, or if the mother is powerless, as in Testimonios sobre Mariana, she at least attempts to protect the child. "Los perros" reminds one more of the pattern found in the work of Rosario Castellanos, in which the mother is more of a patriarchal female, abetting the system in detriment to her daughter. ${ }^{9}$

Rather than see her daughter for what she is, Manuela first focuses on what she is not, that is, that the festival of the village has begun and she and Úrsula have not participated. As she states it, “¡Mira, ya están todos adentro del veintinueve, sólo nosotras andamos por sus orillas! ¡Desgraciado el que se quede afuera de los días señalados, porque será señalado por la desgracia!" (125). Their tardiness is due to Úrsula's hesitancy about attending the fiesta, especially about wearing the special dress prepared for her, a "vestido rosa" (126). In this conflictive interchange with which the play begins, we note that mother and daughter appear to be opponents. Rather than support one another, they "beat about the bush." Manuela does not realize, or acknowledge, that she and her daughter, as women, are on the orillas of the fiesta. No matter what they do, their gender has marked them as outsiders to the fiestas of their society. Úrsula, called a marimacha by her mother for her lack of interest in dressing up, in looking "festive," appears to have intuited what is in store for her if she were to stand out; as a young woman she might catch the eye of 
a male and seal her fate as an object and not as a person of agency. Readers of Garro's fictive world may wonder about the meaning of the vestido rosa, since that is the kind of dress Julia Andrade wore when she was being taken away by Felipe Hurtado in Los recuerdos del porvenir. For Julia, that was a ride of salvation, but in this play, as we learn, Úrsula is not accompanied by a man who would save her, but rather, abuse her. Manuela appears to ignore the danger that plagues her daughter, which one may attribute to naiveté, an erroneous assumption once we learn that Manuela, at Úrsula's age, was abducted from her mother's home and raped by Antonio Rosales, who then kept her captive for seven years. Manuela's mother had searched for her all that time, only to be killed by Antonio when she attempted to reunite with her daughter. These details are unknown to Úrsula and to the audience until the last scenes of the play. In other words, there are no words that pass between the two women that enable them to share past experiences. As Burke observes, "The true action of the play is the dialogue itself. The words spoken and the words deliberately not spoken work together to convey the social reality of the two female characters" (22). Indeed, by not speaking, Manuela condemns her daughter to the same fate she suffered.

Manuela is always afraid of speaking, as if the words have the power to bring disaster: "No digas lo que no debe decirse" (12). When Úrsula attempts to express her fears, her mother's reactions are the exact opposite of what her daughter's situation requires. First, Manuela attempts to silence her: "No quiero oír palabras viejas en boca nueva" (127). For Burke, this retort is uncalled for, and as she notes, [it is] "a strange reply for the context, but which makes sense later after we realize that Úrsula's fear —of Jerónimo, a lecherous man who stalks her when she leaves the house - repeats the same fear that Manuela experienced as a child when she was likewise stalked by Antonio Rosales, Jerónimo's parallel character" (23). In other words, Úrsula's expressions of fears are "palabras viejas"; they have been sounded before, but now Manuela is hearing them pronounced by her own flesh and blood. Nevertheless, she ignores the reality they imply, the reality of her daughter's experiences: “¿Quién ha de fijarse en ti si todavía no has crecido?” (128). Before Úrsula can begin to tell her story of being approached by a man, Manuela again silences her: "No lo repitas, mejor plancha tu vestido" (128). The mother's directive is ironic once we learn the outcome, since her encouragement that Úrsula dress up only hastens the moment of her abduction.

While the interactions between the two female characters certainly confirm their inability to communicate, Garro also shows that this is not a 
gender issue, but one of power relations. Javier, Úrsula's cousin, also feels powerless to help her or to change the cycle of abuse. When he comes to ostensibly warn her that Jerónimo is preparing to carry her off, she is too innocent and trusting to understand why the man wants her. Javier understands all too well the situation, but curiously, he speaks only with Úrsula and not Manuela. That leads one to understand that his motivation is not so much to help Úrsula but, as Burke observes, "to scout out the scene of the crime and guarantee that the child is alone. Javier instructs Úrsula not to tell anyone that he has warned her. While Javier is presumably acting out of self-preservation, his instruction also guarantees that the kidnapping will be carried out as planned" (25). Javier says that he cannot change Jerónimo's mind, because "Mis palabras rebotarían como piedras sobre piedras" (131). He may have the ability to pronounce the words that Manuela will not dare to speak, but he, too, is helpless in the face of the stronger man and his henchmen. Moreover, Javier expresses a belief about spoken words that reflects Manuela's belief about words not spoken: "Y te dije que hay palabras más peligrosas que un cuchillo.... Ahora dicen las palabras terribles y cuando les hayan perdido el miedo, vendrán. Por eso yo vine con sus palabras en mi boca, y no quiero que las repitas, sino que te vayas" (133). Javier came to speak with Úrsula, not with words to protect her, but with "sus palabras en mi boca," that is, the words of danger and abuse that Jerónimo uses to speak about Úrsula as his prey. In a situation in which no words are spoken in truth, Úrsula helplessly admits her own lack of understanding: "no entiendo lo que me dices, primo Javier" (135). There is no Felipe Hurtado to rescue her, nor is she able to leave her home and seek asylum as did Titina. In the penultimate scene of the play, carried out in silence, the audience sees two men enter the home and carry Úrsula away wrapped in sarapes, her voice silenced and her struggle useless. Manuela, meanwhile, is unaware of what has happened and expresses comfort in the erroneous belief that "La suerte no se hereda si no se nombra" (142), a comment her own mother had repeated to her. That she and her mother have held on to an invalid assumption is one of the main ideas of the play. Just as her mother seemed not to have protected Manuela by her own silence, Manuela, too, by keeping her child metaphorically in the dark, turned her back on her when she literally was carried off in the dark of night and under the cover of blankets. The play shows that it is useless to ignore a painful subject in the belief that it will disappear.

Lucía Melgar, calling this play an "obra innovadora y significativa, en particular desde una perspectiva feminista," notices how characters in the 
play act as if "la magia de las palabras es sobre todo una magia "negra"" (Violencia 192). Such a belief supports the culture of silence that surrounds the topic of rape. Moreover, the silences among the characters reflect the silence with which the topic is treated beyond the fictive world. I suggest that Úrsula's kidnapping illustrates Benjamin's idea on the impact of the inability to share experiences, namely the loss of counsel or morals traditionally provided by stories (364). Manuela's story of her abduction and rape and the subsequent murder of her mother are tragic events, but not telling this story to her daughter, superstitiously believing she could not provide good counsel, was not useful, practical, or protective of her daughter's wellbeing. Relinquishing her role as storyteller and keeping silent did not prevent her own story from being played out again in the life of her daughter, but rather resulted in tragedy.

As disturbing as the description of rape is in the play, and as distressing as it is to know that Úrsula suffers this same fate, the play should serve as a warning and a call to action. By speaking out as a writer, Garro accepted her role as storyteller and refused to keep silent about the abuses that characterized her society. By shining a light on the issue, she attempted to prevent yet another disappearance of a helpless young woman.

The need for her message is of course still as relevant in the second decade of the 21 st century as it was in the last half of the previous century. In the words of Melgar, "Su vida en gran medida corresponde a la de una mujer de vanguardia, incomprendida muchas veces por su medio social, a la vez admirada, temida y maltratada.... fue más allá y más a fondo que sus contemporáneas y que muchas de las escritoras actuales" ("Elena Garro" 323). ${ }^{10}$ It is heartening, however, to know that Garro's legacy of commitment to shared experiences and activism is being continued by Melgar and other critics, and by the outstanding writer Sabina Berman, whose screenplay Backyard deals with the theme of rape in Ciudad Juárez. ${ }^{11}$ As Priscilla Meléndez notes, "Berman's paradoxically peripheral position as someone from Mexico City allows her to see that the case of Juárez is connected with national and international systems that are partly to blame for the atrocities that occur there" (28). As I have suggested above, "Los perros" also alludes to the voices from the periphery, the orillas, with Garro's point being that those from the margins need to speak to the cultural systems that are to blame for the atrocities attendant with rape and its dismissal.

While it is not feasible to study in detail all the figures that disappear in Garro's plays, I want to mention, at least briefly, that a number of characters 
decide to leave the world of everyday reality by committing suicide. For example, Clara in "La señora en su balcón" (1963) searches for independence and self-expression in a patriarchal world only to decide that the only way to achieve liberation is to commit suicide. In another example of magical realism, Clara, at the age of 50, engages in a dialogue with herself at different ages - 40, 20, and as a child of 8. Clara, like Anselmo in "El Encanto, Tendejón mixto," searches for a soulmate. She believes she has found a companion in Julio, because they seem to share similar ideas. It turns out, however, that as a man in a patriarchal world, Julio does not condone Clara's need for freedom of action and thought. Seeing his ability to act independently, Clara admits, "Yo quisiera ser tú, para ir a trabajar en la mañana y cruzar la ciudad a la hora en que la cruzan ustedes que son los que hacen mundo. Porque yo la cruzo a la hora en que la cruzan las que hacemos la comida" (42). As Elaine Miller notes, "While the verb hacer indicates that both women and men have the ability to create, Clara wants the ability to create the world, seeking Nineveh with complete freedom as men can do..." (104). Nineveh in this play refers to a place of escape, the ideal city marked by equality of sexes. When Clara realizes that she will never find Nineveh in the world of everyday reality, she takes her destiny in her own hands and decides to leave the world that circumscribes her. She decides to make the great leap to Nineveh, leaving behind the men in her world, or rather, the world of men that is her society. It is possible to believe that suicide is an act of disillusion, but I agree with Miller, who sees Clara's act as one of rebellion and liberation (105).

The plays I have chosen as a way to explore the dramatic function of disappearances illustrate that there is no one way for characters to disappear. Some characters are fortunate to find a guide or companion to help them find a more amenable existence. Others, like Titina, are alone by choice. Unable to find a proper companion, they prefer to absent themselves from the quotidian world. Clara's suicide represents a more extreme choice of evasion in comparison with Titina's isolation in her own world. Whether describing a positive or a negative absence, Garro was able to communicate dramatically this phenomenon of "incommunicability," and, for that reason, we continue to appreciate her texts as well as her genius.

University of Maryland 


\section{Notes}

1 Rebecca Biron, who has studied both the life and fiction of Garro, reminds us that "she consistently blends sociocultural commentary with her individual history, thereby complicating the Mexican reception of her writing, her politics, and her personal choices" ("Un hogar insólito" 140).

2 For further discussion of Garro's role in the events of 1968 and the Tlatelolco massacre, see: Biron, "The Eccentric Elena Garro"; Cypess, Uncivil Wars; Melgar, Writing Dark Times.

3 Remember, too, that the first text that was published after Garro's long hiatus was Andamos huyendo Lola (1980), a collection of short stories that focuses on silences, absences, and the need to avoid persecution. See Petersen and Rojas-Trempe.

4 It is interesting that it is a muleteer who witnesses the magical moment of the disappearance of Julia and Felipe, a figure that is repeated in "El Encanto, Tendajón mixto."

5 Benjamin writes: "With the [First] World War a process began to become apparent which has not halted since then. Was it not noticeable at the end of the war that men returned from the battlefield grown silent—not richer, but poorer in communicable experience?" (362).

6 This ironic process used by Garro is also noted by Amalia Gladhart in reference to the transformation of Isabel Moncada into stone: "At once visible and invisible, the stone body of Isabel becomes an inscribed monument, a double figure of presence and absence" (91).

7 I do not wish to imply that she is a figment of his imagination, but rather, that in the colloquial expression, she represents all he was searching for as an ideal, but was found to be a possibility "en otro tiempo."

8 I want to thank Tanya Huntington for reminding me that in colloquial Mexican Spanish, a lagartona is a "mujer con mucho comillo," an indirect expression for referring to a savvy temptress. By calling the man who propositions Titina "Lagartito," she not only masculinizes the noun but uses a diminutive form of lagartona and appears to be making fun of him, especially when we note that he runs after another woman whom he sees in the street.

9 See the relationship between Zoraida and her daughter in Balún-Canán, or the mother-daughterexchanges in El eterno femenino.

10 These observations are also the focus of Sandra Messinger Cypess, Uncivil Wars: Elena Garro, Octavio Paz and the Battle for Cultural Memory (Austin: U of Texas P, 2012).

${ }^{11}$ See, for example, Lucía Melgar, "Nuestra violencia, nuestra impunidad," Nexos 1 Dec. 2014. Web.

\section{Works Cited}

Benjamin, Walter. "The Storyteller." The Novel: An Anthology of Criticism and Theory 1900-2000. Ed. Dorothy J. Hale. Malden, MA: Blackwell Publishing, 2006. 362-78. Print.

Berman, Sabina. Backyard. Gestos. 20.39 (2005): 109-81. Screenplay.

Biron, Rebecca. "The Eccentric Elena Garro: Critical Confrontations in the 1960s." Torre de Papel 10.2 (2000): 102-17. Print.

. "Un hogar insólito: Elena Garro and Mexican Literary Culture." The Effects

of the Nation: Mexican Art in an Age of Globalization. Eds. Carl Good and John V. Waldron. Philadelphia: Temple UP, 2001. 138-59. Print. 
Burke, Jessica. "Significant Silence in Elena Garro's 'Los Perros." Hispania 93.1 (2010): 23-28. Print.

Callan, Richard J. “Elena Garro’s ‘El Encanto, Tendajón Mixto': The Magical Woman and Maturity." Crítica Hispánica 14.1-2 (1992): 49-57. Print.

Cypess, Sandra Messinger. La Malinche in Mexican Literature: From History to Myth. Austin: U of Texas P, 1991. Print.

. Uncivil Wars: Elena Garro, Octavio Paz, and the Battle for Cultural Memory. Austin: U of Texas P, 2012. Print.

. "Visual and Verbal Distances in the Mexican Theater: The Plays of Elena Garro." Woman as Myth and Metaphor in Latin American Literature. Eds. Carmelo Virgillo and Naomi Lindstrom. Columbia, MO: U of Missouri P, 1985. 44-62. Print.

Garro, Elena. "El Encanto, Tendajón mixto." Un hogar sólido y otras piezas. Xalapa: Universidad Veracruzana, 1983. 103-20. Print.

. "Los perros." Un hogar sólido y otras piezas. Xalapa: Universidad Veracruzana, 1983. 121-42. Print.

. Los recuerdos del porvenir. Mexico City: Joaquín Mortiz, 1963. Print.

. La señora en su balcón. Mexico City: Plaza y Valdés and Consejo Nacional para la Cultura y las Artes, 1994.

Gladhart, Amalia. "Present Absence: Memory and Narrative in Los recuerdos del porvenir." Hispanic Review 73.1 (2005): 91-111. Print.

Meléndez, Priscilla. "The Body and the Law in the Mexico/U.S. Borderlands: Violence and Violations in El viaje de los cantores by Hugo Salcedo and Backyard by Sabina Berman." Modern Drama 54.1 (2011): 24-44. Print.

Melgar, Lucía. "Elena Garro (1916-1998).” Debate Feminista 34 (2006): 321-24. Print.

."Feminicidio y misoginia en México: el hecho y la (violencia de la) palabra." labrys, études féministes/estudos feministas 24 (2013): n. pag. Web. 08 July 2015. . "Nuestra violencia, nuestra impunidad." Nexos 1 Dec. 2014: n. pag. Web. 08 July 2015.

. "Silencios expresivos: gamas y matices del silencio en la obra de Elena Garro." Monographic Review/Revista monográfica 16 (2000): 357-67. Print.

. Violencia y silencio en obras selectas de Elena Garro. Diss. U of Chicago, 1996. Ann Arbor, MI: ProQuest Dissertations Publishing, 1996. Web. 08 July 2015.

Writing Dark Times: Elena Garro, Writing and Politics. Princeton, NJ: Princeton UP, 2000. Print.

Miller, Elaine M. "Acting Women: Gender Roles in Ana Istarú's Hombres en escabeche, Elena Garro's La señora en su balcón, and Carmen Boullosa's Cocinar hombres." Latin American Theatre Review 42.2 (2009): 103-19. Print. 
Mora, Gabriela. "Los perros y La mudanza de Elena Garro: Designio social y virtualidad feminista." Latin American Theatre Review 8.2 (1975): 5-14. Print.

Petersen, Amanda L. "The Unforgettable Phantoms of Elena Garro's 'Debo Olvidar." Chasqui: Revista de Literatura Latinoamericana 43.2 (2014): 192-202. Print.

Poniatowska, Elena. Prólogo. El asesinato de Elena Garro. Periodismo a través de una perspectiva biográfica. Patricia Rosas Lopátegui. Mexico City: Porrúa, 2005. 23-29.

Robles, Martha. Mujeres del Siglo XX. Mexico City: Fondo de Cultura Económica, 2002. Print.

Rojas-Trempe, Lady. "Ex-Patria-Das, locas y escritoras en los cuentos de Elena Garro." Letras Femeninas 29.1 (2003): 87-110. Print.

Toruño-Castañeda, Rhina. "Protesta contra la opresión: categorías medulares en la obra narrativa y dramática de Elena Garro." Deslinde: Revista de la Facultad de Filosofía y Letras de la Universidad Antónoma de Nuevo León 11.35-36 (1992): 93-95. Print. 


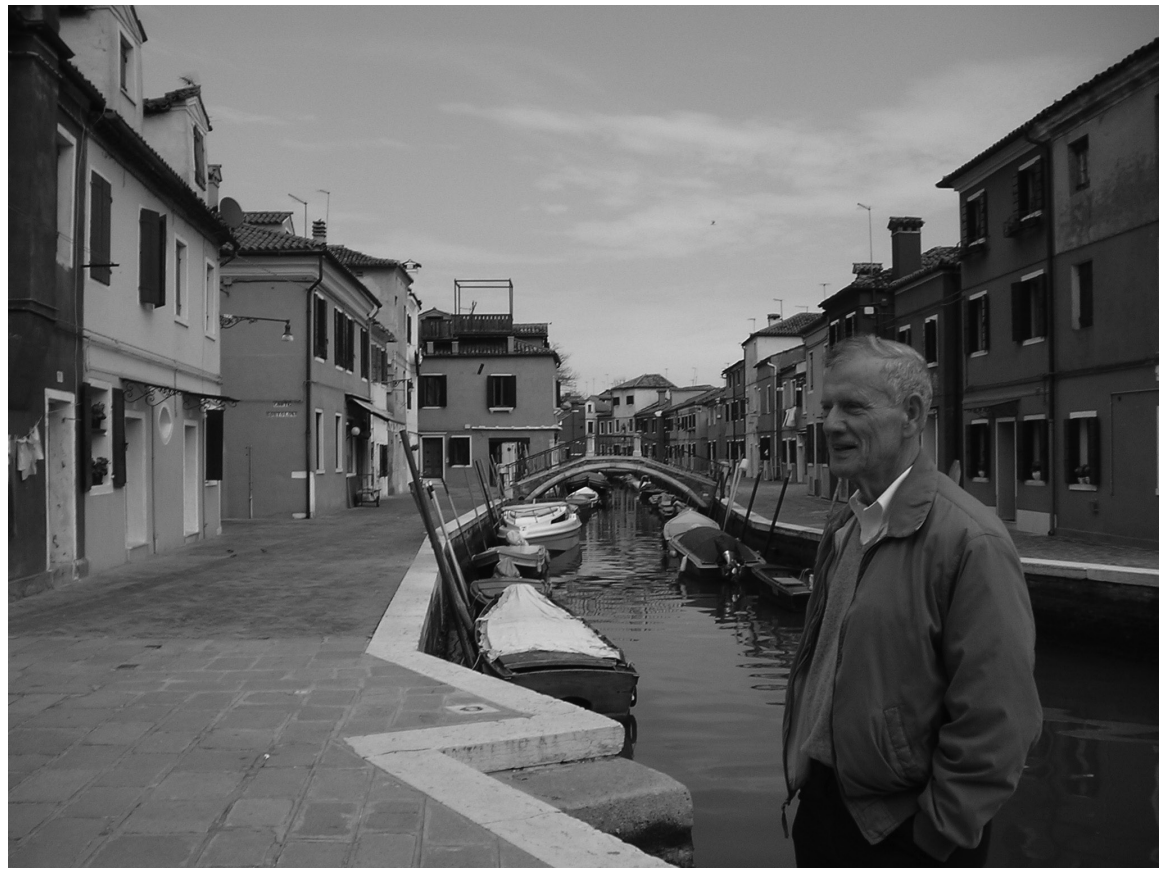

George Woodyard. Photo: Jacqueline E. Bixler. 